\title{
Short-term grazing exclusion effects on riparian small mammal communities
}

\author{
WILLIAM M. GIULIANO AND JOSHUA D. HOMYACK
}

Authors are Assistant Professor, Louis Calder Center - Biological Field Station, Department of Biological Sciences, Fordham University, Armonk, N.Y. 10504 and Wildlife Biologist, USDA Natural Resources Conservation Service, University Park, Penn. 16802.

\begin{abstract}
Grazing of livestock in streams and associated riparian habitats (hereafter referred to as riparian zones) may affect small mammal communities by influencing vegetation, water quality, and other site characteristics. To better understand these effects, we compared vegetation structure, and abundance and richness of small mammals in grazed riparian zones and similar areas where livestock had recently (1-2 years) been excluded in southwest Pennsylvania, 1998 and 1999. Mammalian species richness and abundance (all species combined, meadow voles [Microtus pennsylvanicus Ord], and meadow jumping mice [Zapus hudsonius Zimmermann]) were greater on sites where livestock had been excluded than grazed areas. These findings are likely the result of greater litter cover and increased vertical vegetation obstruction observed on these sites. Because small mammal communities respond quickly to relaxation of grazing in riparian zones, subsidy programs exist to partially pay for fencing, and landowners may potentially benefit from fencing these areas through improved water quality, erosion control, and livestock health, fencing may be an effective wildlife and grazing management tool.
\end{abstract}

Key Words: fencing, litter, livestock, pasture, stream, vegetation, wildlife

Riparian zones typically support a greater diversity and abundance of flora and fauna than surrounding communities (Kauffman and Kruger 1984, Naiman et al. 1993, Belsky et al. 1999). However, $>100,000$ ha of riparian habitat is being altered per year by agricultural activities, with grazing of particular concern (Elmore and Kauffman 1994, Fleischner 1994). Landowners pasture cattle in riparian zones because of the proximity of permanent water and forage, and because these sites are often unsuitable for crop production (Elmore and Kauffman 1994, Fleischner 1994). These practices may modify riparian habitats by altering plant cover, diversity, and composition and contaminating water, which have the potential to impact vertebrate communities. Additionally, grazing livestock may more directly influence vertebrate fauna by trampling or other disturbances (Hayward et al. 1997, Belsky et al. 1999, Belding et al. 2000, Popotnik and Giuliano 2000, Homyack and Giuliano 2002).

Research was funded by Fordham University, California University of Pennsylvania, Richard King Mellon Foundation, and Pheasants Forever. Authors wish to thank D. Bucci, G. Filippone, N. Herbert, and B. Rohrer for help with data collection, and C. Davis and J. Tirpak for comments on drafts of the paper. This is contribution No. 220 of the Louis Calder Center - Biological Field Station, Fordham University.

Manuscript accepted 2 Oct. 03.
Resumen

El apacentamiento de ganado en corrientes de agua y sus hábitats ribereños asociados (de aquí en adelante referidos como zonas ribereñas) puede afectar las comunidades de pequeños mamíferos al influenciar la vegetación, calidad del agua y otras características del sitio. Para entender mejor estos efectos, comparamos la estructura de la vegetación y la abundancia y riqueza de pequeños mamíferos de zonas ribereñas apacentadas con áreas similares donde el ganado había sido excluido recientemente (1-2 años), esto se efectuó en el sudoeste de Pennsylvania durante 1998 y 1999. La riqueza y abundancia de especies de mamíferos (todas las especies combinadas, ratones de pradera [Microtus pennsylvanicus Ord] y ratones saltadores de la pradera [Zapus hudsonius Zimmermann]) fueron mayores en los sitios donde el ganado había sido excluido que en las áreas apacentadas. Estos hallazgos son probablemente el resultado de una mayor cobertura de mantillo y una mayor obstrucción vertical de la vegetación observada en estos sitios. Debido a que las comunidades de pequeños mamíferos responden rápidamente a la suspensión del apacentamiento en las zonas ribereñas, existen programas de subsidio para pagar parcialmente el cercado y los propietarios de la tierra se puedan potencialmente beneficiar del cercado de estas áreas a través de una mejor calidad de agua, un control de la erosión y la salud del ganado, el cercar puede ser una herramienta efectiva de manejo del ganado y fauna silvestre.

In intensively managed pasturelands, the fencing of riparian zones has been proposed as a means of reducing the influence of grazing livestock on these areas and the many wildlife species associated with them (Platts and Wagstaff 1984, Wohl and Carline 1996, Belding et al. 2000). However, data on the effects of grazing on small mammals are scarce, generally limited to the West, and little is known about the possible benefits of livestock exclusion to riparian small mammal communities (Samson et al. 1988, Hayward et al. 1997, Belsky et al. 1999, Chapman and Ribic 2002). Thus, our objectives were to determine if fencing riparian zones to exclude livestock would affect small mammal abundance and richness, and vegetation structure.

\section{Materials and Methods}

Our study was conducted on private farms in and around the Pike Run Watershed of Washington and Greene counties, Pennsylvania, during 1998 and 1999. Most farms raised cattle (Bos taurus L.) as their primary activity, and consisted of pas- 
tures, hayfields (primarily alfalfa [Medicago sativa L.], orchardgrass [Dactylis glomerata L.], timothy [Phleum pretense L.], and switchgrass [Panicum virgatum L.]), cropfields (primarily corn [Zea mays L.]), and scattered woodlots. Riparian vegetation included black cherry (Prunus serotina Ehrhart), black locust (Robinia pseudoacacia L.), cattail (Typha latifolia L.), fescue (Festuca spp. L.), foxtail (Alopecurus aequalis L.), bulrush (Scirpus validus Vahl), goldenrod (Solidago spp. L.), multiflora rose (Rosa multiflora Thunberg), orchardgrass, reed canary-grass (Phalaris arundinacea L.), rice cutgrass (Leersia oryzoides L.), sedge (Carex spp. L.), sweet flag (Acorus calamus L.), willow (Salix spp. L.), and woolgrass (Scirpus cyperinus L.). Pastures containing riparian zones were grazed continuously, with stocking rates ranging from 0.30-0.81 animals/ha.

Since 1995, numerous riparian zones in our study area $\left(040^{\circ} 05^{\prime} 10^{\prime \prime} \mathrm{N}, 079^{\circ} 58^{\prime}\right.$ $45^{\prime \prime} \mathrm{W}$ ) have been fenced (electric) as part of a habitat management program (Belding et al. 2000). In 1998, we paired 9 randomly selected $100 \mathrm{~m}$ sections of ungrazed (i.e., fenced) riparian zone with 9, $100 \mathrm{~m}$ sections of grazed riparian zone based on stream order, vegetation, topography, pre-study stocking rates, and surrounding land use. Livestock had been excluded from ungrazed sites for 1-2 years when the study began. Grazed riparian zones were flagged to approximate the width of paired, ungrazed sections. Individual sections (i.e., experimental units) were located at stream headwaters on different farms and tributaries, and widths varied from $10-15 \mathrm{~m}$.

Two linear drift fence arrays, consisting of $30 \mathrm{~cm}$ tall plastic silt fencing and wooden stakes, were installed perpendicular to the stream bed in each section (Jones et al. 1996, Enge 1997). One fence was placed $20 \mathrm{~m}$ downstream from the upper site boundary, while the other was located on the opposite side of the stream, $80 \mathrm{~m}$ downstream from the same boundary. Drift fences extended from the stream bank to the site boundary. A pitfall trap (18.9 liter plastic bucket) was placed on one end of the drift fence (Jones et al. 1996), and a side-flap pail-trap on the opposite end (Nadorozny and Barr 1997). Elevated bucket lids were used to protect organisms captured in pitfall traps from desiccation and predators (Jones et al. 1996). Locations of pitfall and side-flap pail-traps were reversed between arrays on the same site. A funnel trap (model \#1275, Frabill, Allentown, Wisconsin) was placed at the upstream midpoint of each silt fence, while a second funnel trap was located in the stream bed, directly adjacent to the end of the drift fence array. Sections of silt fencing provided shade for animals captured in terrestrial funnel traps. Traps were checked 3-4 times per week during 1 April-31 July each year.

Vegetation characteristics were quantified at 20 random locations per riparian zone section during the second week of each month, April-July. Sampling locations were stratified by placing 10 sites on each side of the stream bed. We visually estimated percent herbaceous ground and litter cover in $1 \mathrm{~m}^{2}$ quadrats (Bullock 1996), and vertical vegetation obstruction and maximum height, which were measures of both herbaceous and woody vegetation cover present, using a cover pole (Griffith and Youtie 1988). Vegetation variables were estimated for each year by averaging across months. These variables were selected for study because we anticipated they would be affected by grazing livestock and were important to small mammals (DeGraaf and Rudis 1986, Hayward et al. 1997).

Differences in small mammal abundance (total captures) and species richness (number of species), and vegetation variables were analyzed using a single-factor (stream type: grazed vs. ungrazed) repeated measures randomized block ANOVA (SYSTAT 1999, Zar 1999). The blocking factor was stream pairs, and the repeated measure was year.

In addition, we used discriminant function analysis (DFA) to examine which combination of vegetation variables best discriminated ungrazed from grazed sites, and determine the relative importance of each variable in the model. Methods described by Noon (1981) and McGarigal et al. (2000) were used to reduce multicolinearity problems and the number of variables considered in each DFA model. All DFA models were fit using a stepwise forward procedure with Tolerance $=0.001$,

Table 1. Small mammal species (total captures) trapped in riparian zones of Washington and Greene counties, Penn., 1 Apr.-31 Jul., 1998 and 1999.

\begin{tabular}{lcc}
\hline \hline Species & Ungrazed & Grazed \\
\hline Meadow vole (Microtus pennsylvanicus Ord) & 151 & 101 \\
Meadow jumping mouse (Zapus hudsonius Zimmermann) & 128 & 35 \\
Short-tailed shrew (Blarina brevicauda Say) & 57 & 24 \\
White-footed mouse (Peromyscus leucopus Rafinesque) & 18 & 1 \\
Hairy-tailed mole (Parascalups breweri Bachman) & 13 & 2 \\
Masked shrew (Sorex cinereus Kerr) & 13 & 1 \\
Black rat (Rattus rattus L.) & 2 & 7 \\
Norway rat (Rattus norvegicus Berkenhout) & 7 & 1 \\
Muskrat (Ondatra zibithicus L.) & 2 & 0 \\
Least weasel (Mustela nivalis L.) & 2 & 0 \\
Deer mouse (Peromyscus maniculatus Wagner) & 1 & 0 \\
House mouse (Mus musculus L.) & 1 & 1 \\
Eastern chipmunk (Tamias striatus L.) & 0 & \\
\hline
\end{tabular}

F-to-enter $=0.15$, and F-to-remove $=0.15$. The order in which variables enter the model can affect final model selection, and there is no widely accepted method of determining the order of variable entry into a model. Therefore, models were fit by entering variables into the model in all possible orders (SYSTAT 1999, McGarigal et al. 2000). The relative importance of each variable in the final model was assessed by examining standardized canonical discriminant functions (SCDF; i.e., variables with higher SCDF values made greater individual contributions to the discriminating power of the model; McGarigal et al. 2000). Because mixing continuous (e.g., vegetation height) and categorical (e.g., year) data within a model is not widely accepted, and categorical data may violate certain model assumptions (McGarigal et al. 2000), separate DFA's were conducted for each year of the study.

Model assumptions were tested for all analyses (Zar 1999, McGarigal et al. 2000). When data failed to meet 1 or more of the assumptions, they were rank transformed prior to analysis (Conover and Iman 1981, Zar 1999). SYSTAT software was used to conduct all statistical analyses (SYSTAT 1999), and tests were considered significant at $\mathrm{P} \leq 0.10$, rather than the more typical $P \leq 0.05$, to reduce the likelihood of committing a Type II error (Zar 1999). For DFA's, we also examined canonical correlations and jackknifed classification matrices to assess the final model (SYSTAT 1999, McGarigal et al. 2000).

\section{Results}

Thirteen small mammal species were captured on ungrazed and grazed sites (Table 1). Species richness was 1.7 times 
Table 2. Characteristics of small mammal communities and selected individual species captured in ungrazed and grazed riparian zones of Washington and Greene counties, Penn., 1 Apr.-31 Jul., 1998 and 1999.

\begin{tabular}{|c|c|c|c|c|c|}
\hline \multirow[b]{2}{*}{ Variable } & \multicolumn{2}{|c|}{ Ungrazed $(n=18)$} & \multicolumn{2}{|c|}{ Grazed $(n=18)$} & \multirow[b]{2}{*}{$\mathrm{P}$} \\
\hline & Mean & SE & Mean & SE & \\
\hline Species richness (number of species) & 4.4 & 0.3 & 2.6 & 0.3 & 0.001 \\
\hline Abundance (total number of captures) & 21.2 & 2.6 & 9.7 & 1.8 & $\leq 0.001$ \\
\hline Meadow vole (Microtus pennsylvanicus Ord; number of captures) & 8.0 & 1.1 & 5.3 & 0.9 & 0.079 \\
\hline Meadow jumping mouse (Zapus hudsonius Zimmermann; number of captures) & 9.1 & 2.3 & 3.5 & 1.4 & 0.014 \\
\hline Short-tailed shrew (Blarina brevicauda Say; number of captures) & 3.8 & 0.6 & 2.4 & 0.5 & 0.144 \\
\hline
\end{tabular}

greater on ungrazed than grazed sites (Table 2), but no year $(\mathrm{P}=0.832)$ or interaction effects (site $\mathrm{x}$ year; $\mathrm{P}=0.283$ ) were found. Small mammal abundance was 2.2 times greater on ungrazed than grazed sites (Table 2), did not differ between years $(\mathrm{P}=0.650)$, and no interaction $(\mathrm{P}=$ 0.240 ) was detected. Of the 3 species captured in sufficient numbers $(>20)$ to permit individual analysis (Table 2), meadow voles and meadow jumping mice were more abundant in ungrazed sites, while short-tailed shrews did not differ in abundance between site types (Table 2). No year or interaction effects were obtained for meadow voles and meadow jumping mice $(P>0.10)$. However, short-tailed shrews were more abundant in 1999 than $1998(P=0.047)$, and a year $x$ site interaction existed $(\mathrm{P}=0.068)$.

Litter cover was 2.3 times greater in ungrazed sites (Table 3 ) and greater in 1999 than $1998(\mathrm{P}=0.001)$, with a site $\mathrm{x}$ year interaction $(P=0.036)$. Herbaceous ground cover was 1.1 times greater in grazed than ungrazed sites (Table 3 ), greater in 1999 than $1998(\mathrm{P} \leq 0.001)$, and we found an interaction between site and year $(P=0.005)$. Vertical vegetation obstruction was greater in ungrazed than grazed sites (Table 3) and greater in 1998 than $1999(\mathrm{P}=0.006)$, but no interactions between site and year existed $(P=0.198)$. Vegetation height did not differ between site types (Table 3), was greater in 1999 than $1998(\mathrm{P}=0.001)$, and we found a site $x$ year interaction $(\mathrm{P} \leq 0.001)$.

For 1998, litter cover alone best discriminated grazed from ungrazed sites $(P$ $\leq 0.001$ ), correctly classifying $78 \%$ of the sites and having a canonical correlation of 0.527. However, during 1999 litter cover

Table 3. Vegetation characteristics of ungrazed and grazed riparian zones of Washington and Greene counties, Penn., 1 Apr.-31 Jul., 1998 and 1999.

\begin{tabular}{lccrrr}
\hline \hline & \multicolumn{4}{c}{ Ungrazed $(\mathrm{n}=18)$} & \multicolumn{2}{c}{ Grazed $(\mathrm{n}=18)$} & \\
Variable & Mean & $\mathrm{SE}$ & Mean & SE & \multicolumn{1}{c}{$\mathrm{P}$} \\
\hline Litter cover (\%) & 21.2 & 1.6 & 9.4 & 1.1 & $\leq 0.001$ \\
Herbaceous ground cover (\%) & 68.9 & 1.8 & 74.4 & 1.4 & 0.028 \\
Vertical vegetation obstruction (index) & 9.7 & 0.6 & 6.1 & 0.6 & 0.005 \\
Vegetation height $(\mathrm{cm})$ & 10.5 & 0.6 & 11.5 & 0.7 & 0.323 \\
\hline
\end{tabular}

and vertical vegetation obstruction together best discriminated grazed from ungrazed sites $(P \leq 0.001)$, correctly classifying $85 \%$ of sites and having a canonical correlation of 0.643 , with vertical vegetation obstruction $(\mathrm{SCDF}=0.886)$ being of greater importance than litter cover $(\mathrm{SCDF}=0.669)$. Final models for both years did not change when variables were entered in different orders.

\section{Discussion and Conclusions}

Compared with continuously grazed riparian zones, areas not grazed for 1-3 years supported a greater abundance and richness of small mammals. Many small mammals are microhabitat-dependent (Grant et al. 1982, DeGraaf and Rudis 1986, Rosenstock 1996, Chapman and Ribic 2002). Thus, we believe higher small mammal abundance and richness was likely related to the increased vegetative cover and structure found on ungrazed sites. Our data suggest that greater amounts of litter and vegetation obstruction on ungrazed areas provided small mammals with additional cover, than more open, grazed sites, which may provide protection while foraging, and proper microclimates for small mammals and their prey. Although herbaceous ground cover was greater in grazed areas, we believe it was of little value, as food or cover, to most small mammals because it was generally grazed to $<2 \mathrm{~cm}$. Despite the fact that we conducted our study in a different ecosystem, our results are consistent with Kauffman and Kruger (1984), Hayward et al. (1997), Belsky et al.
(1999), and Chapman and Ribic (2002), who found that grazing negatively affected populations of many small mammal species through reductions in cover. Additionally, Hayward et al. (1997) observed grazing cattle trampling individuals and burrows, and compacting soils, which affected several species in the Southwest. Because we did not directly assess these impacts, we can not quantify their importance to small mammals on our areas. However, given other similarities between our work and that of Hayward et al. (1997), it is possible that these affects were also important on our sites.

Of the 3 species for which we examined individual abundance, the 2 herbivorous species (meadow voles and meadow jumping mice; DeGraaf and Rudis 1986) were more abundant on ungrazed sites, while short-tailed shrews, which feed primarily on invertebrates (DeGraaf and Rudis 1986), were found in equal numbers in each site type. This pattern is expected, because many species are likely dependent on vegetation for food and cover (Grant et al. 1982, Bock et al. 1984, Rosenstock 1996, Hayward et al. 1997, Belsky et al. 1999, Chapman and Ribic 2002). Thus, meadow voles and meadow jumping mice, which depend directly on vegetation for food, may benefit more from cattle exclusion than short-tailed shrews. In a separate study of our riparian zones, we observed little difference in invertebrate communities between grazed and ungrazed sites (Homyack and Giuliano 2002), possibly explaining the lack of response of the insectivorous, short-tailed shrews. Alternatively, it is possible that the presence of grazing livestock may enhance conditions for some small mammal species requiring more open vegetation communities (Hayward et al. 1997) or invertebrates associated with livestock (e.g., because of increased fecal loads). However, our data did not support this conclusion.

Because livestock had only been excluded from riparian zones in our study for $<4$ years, some site conditions may not have changed sufficiently from the effects of 
past grazing to significantly affect small mammal population growth and persistence, and thus current abundance, species richness, and community composition. Additionally, isolation from other populations and inherent dispersal limitations may reduce the rate at which small mammal species recolonize ungrazed riparian zones following livestock exclusion (Noss 1983, Fahrig and Merriam 1985, Gregory et al. 1991). Furthermore, because livestock had only been excluded for a short time, ungrazed areas may still be in a transitory state (i.e., continuing to exhibit changes in vegetation structure and composition), which may result in a dynamic small mammal community (i.e., changing species abundances and composition). Our finding that litter and herbaceous ground cover, vegetation height, vertical vegetation obstruction, and short-tailed shrew abundance changed with time supports this conclusion. However, longer-term research is needed to adequately address these issues.

Three species captured during this study were not native (house mouse [Mus musculus L.], black rat [Rattus rattus L.], and Norway rat [Rattus norvegicus Berkenhout]). Typically consider pests, these species may cause damage to crops and structures, spread disease, and outcompete native species for resources within riparian zones (Marsh 1994, Timm 1994a, 1994b). However, all of these species were captured relatively infrequently on only 3 sites, and 2 of the 3 species were found in both grazed and ungrazed riparian zones. Thus, we do not believe that the presence of these non-native species had a significant impact on the small mammal communities in our study, or on our comparisons, conclusions, or recommendations.

Because small mammal and other wildlife communities (e.g., fish [Platts and Wagstaff 1984], birds [Popotnik and Giuliano 2000], and some herpetofauna [Homyack and Giuliano 2002]) are benefited by livestock exclusion from riparian zones, we believe fencing of such areas can be an important wildlife habitat and grazing management practice. Further, stream bank fencing of riparian zones can be a practical land management tool in many areas because (1) farmers and ranchers may potentially realize benefits from improved livestock health and production, improved water quality and quantity, and erosion control (USDA 1998, Belding et al. 2000), and (2) numerous state and federal programs subsidize the cost of stream bank fencing and development of alternative livestock watering systems (e.g., U.S. Fish and Wildlife Service Partners for Wildlife
Program and USDA Wetlands Reserve, Conservation Reserve, Conservation Reserve Enhancement, Wildlife Habitat Incentives, and Environmental Quality Incentives Programs; USDA 1998, Belding et al. 2000).

\section{Literature Cited}

Belding, R.B., W.M. Giuliano, D. Putnam, and J. Taracido. 2000. Integrating wildlife management and agriculture: conserving biodiversity through long-term partnerships, $p$. 48-51. In: G.D. Therres (ed.) Conservation of biodiversity: a key to the restoration of the Chesapeake Bay ecosystem and beyond. Md. Dept. Natur. Resources, Annapolis, Md.

Belsky, A.J., A. Matzke, and S. Uselman. 1999. Survey of livestock influences on stream and riparian ecosystems in the western United States. J. Soil Water Conserv. 54:419-431.

Bock, C.E., J.H. Bock, W.R. Kenny, and V.M. Hawthorne. 1984. Responses of birds, rodents, and vegetation to livestock exclosure in a semidesert grassland site. J. Range Manage. 37:239-242.

Bullock, J. 1996. Plants, p. 111-138. In: W.J. Sutherland (ed.) Ecological census techniques: a handbook. Cambridge Univ. Press, New York, N.Y.

Chapman, E.W. and C.A. Ribic. 2002. The impact of buffer strips and stream-side grazing on small mammals in southwestern Wisconsin. Agr., Ecosystems, and the Environ. 88:49-59.

Conover, W.J. and R.L. Iman. 1981. Rank transformation as a bridge between parametric and nonparametric statistics. Amer. Statist. 35:124-133.

DeGraaf, R.M. and D.D. Rudis. 1986. New England wildlife: habitat, natural history, and distribution. U.S. Forest Service, General Tech. Rep. NE-108.

Elmore, W. and B. Kauffman. 1994. Riparian and watershed systems: degradation and restoration, p. 212-231. In: M. Vavra, W.A. Laycock, and R.D. Pieper (ed.) Ecological implications of livestock herbivory in the West. Soc. for Range Manage., Denver, Colo.

Enge, K.M. 1997. Use of silt fencing and funnel traps for drift fences. Herpetological Rev. 28:30-31.

Fahrig, L. and G. Merriam. 1985. Habitat patch connectivity and population survival. Ecol. 66:1762-1768.

Fleischner, T.L. 1994. Ecological costs of livestock grazing in Western North America. Conservation Biology 8:629-644.

Grant, W.E., E.C. Birney, N.R. French, and D.M. Swift. 1982. Structure and productivity of grassland small mammal communities related to grazing-induced changes in vegetative cover. J. Mamm. 63:248-260.
Gregory, S.V., F.J. Swanson, W.A. McKee, and K.W. Cummins. 1991. An ecosystem perspective on riparian zones. BioScience 41:540-551.

Griffith, B. and B.A. Youtie. 1988. Two devices for estimation of foliage density and deer hiding cover. Wildl. Society Bull. 16:206-210.

Hayward, B., E.J. Heske, and C.W. Painter. 1997. Effects of livestock grazing on small mammals at a desert cienaga. J. Wildl. Manage. 61:123-129.

Homyack, J.D. and W.M. Giuliano. 2002. Effect of streambank fencing on herpetofauna in pasture stream zones. Wildl. Soc. Bull. 30:361-369.

Jones, C., W.J. McShea, M.J. Conroy, and T.H. Kunz. 1996. Capturing mammals, p. 115-156. In: D.E. Wilson, F.R. Cole, J.D. Nichols, R. Rudran, and M.S. Foster (eds.) Measuring and monitoring biological diversity: standard methods for mammals. Smithsonian Inst. Press, Washington D.C.

Kauffman, J.B. and W.C. Kruger. 1984. Livestock impacts on riparian ecosystems and streamside management implications...a review. J. Range Manage. 37:430-437.

Marsh, R.E. 1994. Roof rats, p. 125-132. In: S.E. Hygnstrom, R.M. Timm, and G.E. Larson (eds.) Prevention and control of wildlife damage. Univ. Neb. Coop. Ext., Great Plains Agr. Counc., and USDA-APHIS Anim. Damage Control, Lincoln, Neb.

McGarigal, K., S. Cushman, and S. Stafford. 2000. Multivariate statistics for wildlife and ecology research. Springer, New York, N.Y.

Nadorozny, N.D. and E.D. Barr. 1997. Improving trapping success of amphibians using a side-flap pail-trap. Herpetological Rev. 28:193-194.

Naiman, R., H. Decamps, and M. Pollack. 1993. The role of riparian corridors in maintaining regional diversity. Ecol. Appl. 3:209-211.

Noon, B.R. 1981. The distribution of an avian guild along a temperate elevational gradient: the importance and expression of competition. Ecol. Monogr. 51:105-125.

Noss, R.F. 1983. A regional approach to maintain diversity. BioScience 33:700-706.

Platts, W.S. and F.J. Wagstaff. 1984. Fencing to control livestock grazing on riparian habitats along streams: is it a viable alternative. North Amer. J. Fisheries Manage. 4:266-272.

Popotnik, G.J. and W.M. Giuliano. 2000. Response of birds to grazing of riparian zones. J. Wildl. Manage. 64:976-982.

Rosenstock, S.S. 1996. Shrub-grassland small mammal and vegetation responses to rest from grazing. J. Range Manage. 49: 199-203.

Samson, F.B., F.L. Knopf, and L.B. Haas. 1988. Small mammal response to the introduction of cattle into a cottonwood floodplain, p. 432-438. In: R.C. Szaro, K.E. Severson, and D.R. Patton (eds.) Management of amphibians, reptiles, and small mammals in North America. U. S. Forest Service, Gen. Tech. Rep. RM-166. 
SYSTAT. 1999. System for windows: Statistics, Version 5 Systat, Inc., Evanston, Ill.

Timm, R.M. 1994a. House mice, p. 31-38. In: S.E. Hygnstrom, R.M. Timm, and G.E. Larson (eds.), Prevention and control of wildlife damage. Univ. Neb. Coop. Ext., Great Plains Agr. Counc., and USDA-APHIS Anim. Damage Control, Lincoln, Neb.
Timm, R.M. 1994b. Norway rats, p. 105-120. In: S.E. Hygnstrom, R.M. Timm, and G.E. Larson (eds.), Prevention and control of wildlife damage. Univ. Neb. Coop. Ext., Great Plains Agr. Counc., and USDA-APHIS Anim. Damage Control, Lincoln, Neb.

USDA. 1998. The USDA's Natural Resources programs: financial, technical, and educational assistance for landowners. USDA, Washington D. C.
Wohl, N.E. and R.F. Carline. 1996. Relations among riparian grazing, sediment loads, macroinvertebrates, and fishes in three Pennsylvania streams. Can. J. Fisheries and Aquatic Sci. 53:260-266.

Zar, J.H. 1999. Statistical Analysis. Prentice Hall, Englewood Cliffs, N.J. 